Part of Journal of Research of the National Bureau of Standards, Volume 26, May 1941

\title{
METASTABILITY OF CADMIUM SULFATE AND ITS EFFECT ON ELECTROMOTIVE FORCE OF SATURATED STANDARD CELLS
}

\author{
By George W. Vinal and Langhorne H. Brickwedde
}

\section{ABSTRACT}

Both solubility and electromotive force measurements are concordant in fixing the transition temperature of $\mathrm{CdSO}_{4} \cdot 8 / 3 \mathrm{H}_{2} \mathrm{O}$ to $\mathrm{CdSO}_{4} \cdot \mathrm{H}_{2} \mathrm{O}$, at $43.4^{\circ} \mathrm{C}$. Previously the transition temperature was generally believed to be $74^{\circ} \mathrm{C}$. Cells recently were made with each modification. Their respective electromotive forces differ except at the transition temperature, where they, as well as the solubilities, are equal. The temperature coefficient of cells containing $\mathrm{CdSO}_{4} \cdot \mathrm{H}_{2} \mathrm{O}$ was found to be positive, whereas the temperature coefficient for cells containing the ordinary salt $\mathrm{CdSO}_{4} \cdot 8 / 3 \mathrm{H}_{2} \mathrm{O}$ is negative, as is well known. Both hydrates tend to persist in a metastable state, and measurements can be made over a wide range of temperatures. The free energy changes of the cells are discussed, and some practical applications for the cells are described.

\section{CONTENTS}

Page

I. Introduction

II. Experimental procedure _.

1. Solubility determinations

2. Construction of cells

3. Temperature control of the cells and measurement of electromotive force

III. Experimental results

1. Solubility measurements $\ldots \ldots \ldots 8$

2. Electromotive force

3. Temperature coefficient $\ldots \ldots \ldots 1$

IV. Thermodynamic discussion of the reaction $\ldots \ldots \ldots . \ldots 2$

V. Hysteresis effects

VI. Conclusions

VII. References........

\section{INTRODUCTION}

Contrary to the generally accepted opinion, the transition point of cadmium sulfate from $\mathrm{CdSO}_{4} \cdot 8 / 3 \mathrm{H}_{2} \mathrm{O}$ to $\mathrm{CdSO}_{4} \cdot \mathrm{H}_{2} \mathrm{O}$ occurs at a temperature much below that stated in the literature $[1]^{1}$ dealing with standard cells. For more than 40 years this transition point was believed to be about $74^{\circ} \mathrm{C}$, which is safely above any reasonable temperature at which standard cells might be used, and also above any necessary temperature for the preparation of the crystalline salt. Apparently the value $74^{\circ} \mathrm{C}$, reported in 1897 by Mylius and Funk [1], is the basis for many of the statements made by other authors who wrote at a later date.

\footnotetext{
1 Figures in brackets indicate the literature references at the end of this paper.
} 
Other papers written without reference to standard cells have indicated anomalies in the behavior of cadmium sulfate. Thus Hofman and Wanjukow [2] concluded, as a result of heating cadmium sulfate in a muffle furnace, that some water is separated from $\mathrm{CdSO}_{4}$. $8 / 3 \mathrm{H}_{2} \mathrm{O}$ at $30^{\circ} \mathrm{C}$ or below and additional water is separated at $41^{\circ} \mathrm{C}$. Carpenter and Jette [3] in the course of vapor-pressure measurements found indication of a discontinuity in their curve for the salt at about $41.5^{\circ} \mathrm{C}$ and concluded that this was a transition point.

Reasons can be advanced for the uncertainty in determining the transition temperature. They are based largely on the somewhat unusual properties of the salt in solution. Cadmium sulfate, $\mathrm{CdSO}_{4}$. $8 / 3 \mathrm{H}_{2} \mathrm{O}$, is slow to go into solution, although it is very soluble. The monohydrate, $\mathrm{CdSO}_{4} \cdot \mathrm{H}_{2} \mathrm{O}$, whose solubility decreases with rising temperature, is even slower in crystallizing out of solution. Both salts tend to form supersaturated solutions, and considerable time is required to attain saturation equilibrium. In the light of our present experience, we think that Mylius and Funk allowed insufficient time for the transition to occur. They reported agitating the solutions for 1 hour. We have found, however, that solutions containing the metastable phase may be agitated at $45^{\circ} \mathrm{C}$ for a week or more without the appearance of the stable form. The time required for the metastable form to be converted into the stable form decreases as the temperature is raised. At $74^{\circ}$ or above, the time is probably reduced sufficiently for the transition to occur under conditions of their experiment.

Metastable states of the Clark standard cell (zinc cell) were recognized many years ago [4]. In this cell the transition from $\mathrm{ZnSO}_{4} .7 \mathrm{H}_{2} \mathrm{O}$ to $\mathrm{ZnSO}_{4} \cdot 6 \mathrm{H}_{2} \mathrm{O}$ occurs at about $39^{\circ} \mathrm{C}$, as shown by both solubility and emf data. The fact that such a cell might have two differing electromotive forces at a specified temperature was considered an objection to its use as a standard of emf.

Several early investigators believed that irregularities which they observed in cadmium standard cells at about $15^{\circ} \mathrm{C}$ were caused by a transition of the cadmium salt. Subsequently, it was shown by others that this was the result of using too high percentages of cadmium in the amalgam, which undoubtedly consisted of the solid phase alone at this temperature. No further discussion of this point is warranted here, but reference may be made to a short summary given by Wolff and Waters [5]. Aside from this discussion about 40 years ago, it has generally been believed that the saturated Weston cell was not subject to irregularities resulting from metastable conditions of the cadmium salt.

The fact that the present work shows that the transition point for cadmium sulfate is only 4 or 5 degrees higher than for zinc sulfate should not be interpreted as being a serious objection to the use of the cadmium cells. The National Bureau of Standards has for years cautioned users of standard cells not to subject them to temperatures higher than $40^{\circ} \mathrm{C}$. Forty degrees is above any ordinary operating temperatures for the cells; but what is more important, the newly determined transition temperature fixes an upper limit for the preparation of the crystallized salt. Exposure of cells to temperatures above the transition point does not necessarily mean that the cells will be seriously damaged. Experiments indicate that the usual form of crystallized salt persists in a metastable state considerably above the transition temperature. During the past 16 years several groups of saturated cells which had been grossly overheated have been tested. 
Some of these had abnormal emf, while others were apparently not damaged.

Another hydrate of cadmium sulfate of somewhat uncertain composition was reported by Mylius and Funk to exist at temperatures of $0^{\circ} \mathrm{C}$ or below. They report this to be $\mathrm{CdSO}_{4} \cdot 7 \mathrm{H}_{2} \mathrm{O}$. We have made no study of it.

In this paper it is shown that solubility and emf measurements are concordant in fixing the transition temperature of $\mathrm{CdSO}_{4} \cdot 8 / 3 \mathrm{H}_{2} \mathrm{O}$ to $\mathrm{CdSO}_{4} \cdot \mathrm{H}_{2} \mathrm{O}$ at $43.4^{\circ} \mathrm{C}$. Cells made with each of these hydrates are compared. Electromotive forces of such cells differ except at the transition point. The monohydrate salt produces cells with a positive temperature coefficient in contrast to the others which have a negative coefficient. Solubilities in the metastable condition are higher and resulting emf lower than when the cells contain the stablemodifications. Free energy changes of the cells are discussed.

\section{EXPERIMENTAL PROCEDURE}

\section{SOLUBILITY DETERMINATIONS}

The solubility determinations are a part of a larger project involving the determination of solubilities in ordinary water and in deuterium oxide. These measurements were a necessary preliminary to the construction of cells containing high percentages of $\mathrm{D}_{2} \mathrm{O}$. The methods and results will be given in greater detail in another paper on the deuterium cells. For the present purpose, it is sufficient to state that widely different results for the solubility of cadmium sulfate in normal water at $50^{\circ} \mathrm{C}$ agreed no better after many repetitions in various temperature-controlled air and water baths. Samples of the crystals were examined microscopically by C. P. Saylor, who reported two modifications to be present. Throughout the course of the work Dr. Saylor kindly examined many samples for us, and his reports have been an indispensable guide in the conduct of this work.

Gravimetric determinations to identify the crystals of the solid phase were made, and the modification stable at the higher temperatures was found to be $\mathrm{CdSO}_{4} \cdot \mathrm{H}_{2} \mathrm{O}$, while that which is stable at the lower temperatures was found to be $\mathrm{CdSO}_{4} \cdot 8 / 3 \mathrm{H}_{2} \mathrm{O}$. By seeding the solutions with the proper kind of crystals, reproducible results could be obtained if certain obvious precautions were taken.

Analyses of the various solutions were made by evaporating samples to dryness and weighing the salt as $\mathrm{CdSO}_{4}$ after it had been dehydrated at a temperature of $650^{\circ}$ to $700^{\circ} \mathrm{C}$ in a muffle furnace. A trace of $\mathrm{SO}_{3}$ was always present in the atmosphere of the furnare to prevent any possible decomposition.

\section{CONSTRUCTION OF CELLS}

The cadmium salt was a purified sample prepared for making standard cells. This was dehydrated in a muffle furnace, and subsequently the monohydrate crystals were grown in a solution at $85^{\circ} \mathrm{C}$.

Some variations in the usual method of making the cells were necessary because of the metastability of $\mathrm{CdSO}_{4} \cdot \mathrm{H}_{2} \mathrm{O}$ at ordinary room temperatures. To have washed the mercurous sulfate in a Gooch crucible with the saturated solution of this hydrate might have re- 
sulted in seeding the paste with the other kind of crystals. A procedure sometimes used by Wolff and Waters [6] many years ago was followed. Mercurous sulfate for all the cells was washed with absolute alcohol and then with dried ether. Paste for two cells containing $\mathrm{CdSO}_{4} .8 / 3 \mathrm{H}_{2} \mathrm{O}$ was then prepared in the ordinary manner at room temperature. For the two monohydrate cells it was necessary to keep the materials hot. This was done in an oven with the thermostat set for $85^{\circ} \mathrm{C}$. The paste was prepared from the mercurous sulfate, the hot saturated solution, and crystals of $\mathrm{CdSO}_{4} \cdot \mathrm{H}_{2} \mathrm{O}$. The paste was introduced as quickly as possible into the cells, which also had been heated. Blanks with ground-glass stoppers were used, and these were sealed with collodion.

\section{TEMPERATURE CONTROL OF THE CELLS AND MEASUREMENT OF ELECTROMOTIVE FORCE}

The cells were placed in an oil bath with thermostatic control, variations from any specified temperature amounting to about $\pm 0.05^{\circ} \mathrm{C}$. The emf measurements at various temperatures were made directly against the Bureau's reference cell, which is a part of the primary standard of emf maintained always at $28^{\circ} \mathrm{C}$. When the differences in emf of the cells under test from the reference cell were not more than 0.002 volt, the readings could be made on the comparator described by Brooks [7]. Otherwise, measurements were made on a Wolff potentiometer.

Because of slight variations in temperature of the oil bath and the large temperature coefficient of cells containing the high-temperature modification of $\mathrm{CdSO}_{4}$, the emf readings are significant to about 10 microvolts. This, however, is sufficiently accurate for the present purpose.

Temperatures of the oil bath were read on a calibrated mercury thermometer which had a range of $-11^{\circ}$ to $+53^{\circ} \mathrm{C}$, graduated to tenths of a degree. All corrections, including that for the emergent stem, have been applied.

Successive measurements at decreasing temperatures could be made rather quickly as the cells had little hysteresis. Many exploratory observations were made, but these have been omitted from table 2, which is limited to the observations for which ample time was allowed for equilibrium conditions to be attained. Rising temperatures, however, resulted in considerable hysteresis of the cells containing the monohydrate salt. This is further discussed in later paragraphs.

\section{EXPERIMENTAL RESULTS}

\section{SOLUBILITY MEASUREMENTS}

Determinations of the solubility of both modifications of cadmium sulfate are plotted in figure 1 , and values at regular temperature intervals read from the curves are given in table 1. All of the values are the result of measurements made during the present work, with the one exception of that at $10^{\circ} \mathrm{C}$, which has been taken from the International Critical Tables [8]. This is marked ICT in the table and in the figure. No determination was made by us at this point 
because of the difficulty in maintaining this temperature during the long period of shaking the solutions.

TABLE 1.-Solubilities of cadmium sulfate

\begin{tabular}{|c|c|c|}
\hline \multirow{2}{*}{ Temperature } & \multicolumn{2}{|c|}{$\begin{array}{l}\text { Solubility (mole of } \mathrm{CdSO}_{4} \\
\text { per mole of } \mathrm{H}_{2} \mathrm{O} \text { ) }\end{array}$} \\
\hline & $\mathrm{CdSO}_{4}, 8 / 3 \mathrm{H}_{2} \mathrm{O}(\mathrm{s})$ & $\mathrm{CdSO}_{4} \cdot \mathrm{H}_{2} \mathrm{O}(\mathrm{s})$ \\
\hline $\begin{array}{l}{ }^{\circ} \mathrm{C} \\
0 \\
10 \text { (ICT) } \\
15 \\
20 \\
25 \\
30 \\
35 \\
40 \\
43.4 \\
45 \\
50 \\
60\end{array}$ & $\begin{array}{c}0.0655 \\
.06555 \\
.06566 \\
.06583 \\
.06607 \\
.06642 \\
.06693 \\
.06767 \\
.06828 \\
.06860 \\
.06964 \\
\end{array}$ & $\begin{array}{c} \\
0.06828 \\
.06792 \\
.06686 \\
0649\end{array}$ \\
\hline
\end{tabular}

The solubilities are expressed as moles of $\mathrm{CdSO}_{4}$ in 1 mole of $\mathrm{H}_{2} \mathrm{O}$. This is necessary as the other part of the work (not reported here) included similar determinations in $\mathrm{D}_{2} \mathrm{O}$. Saturation equilibrium

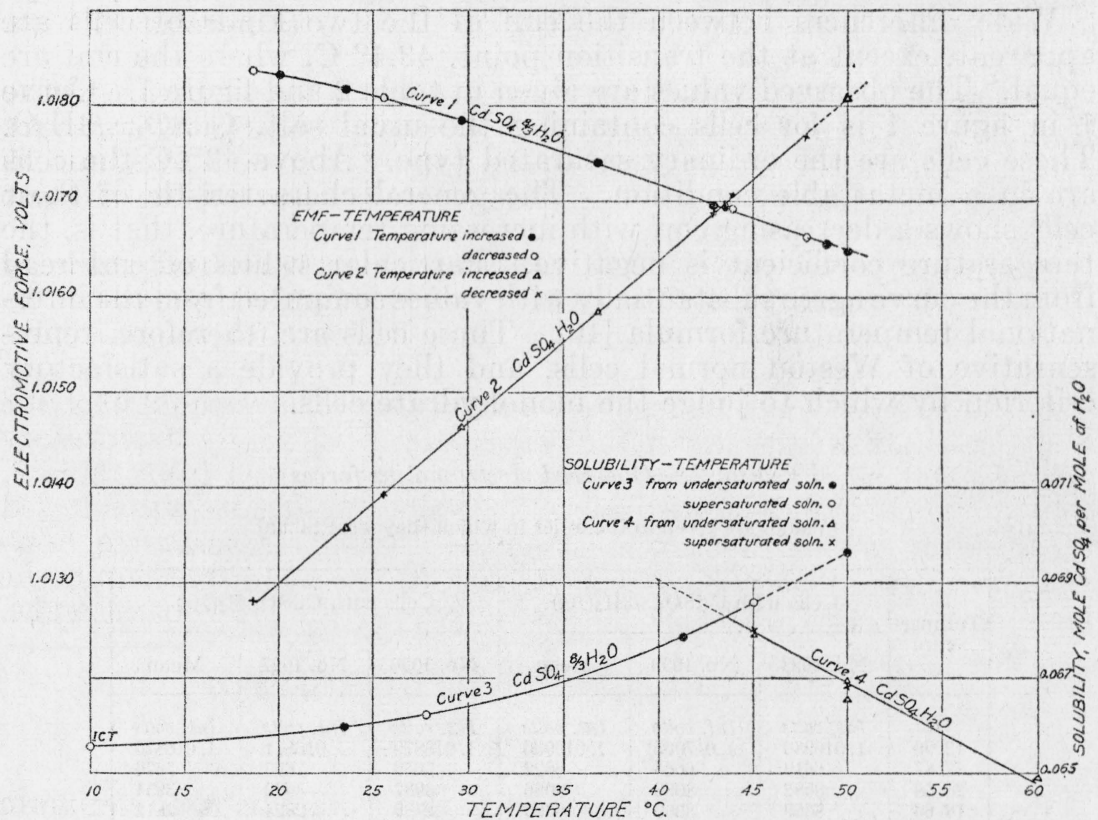

FigURE 1.-Electromotive force and solubility measurements as a function of temperature.

Intersections at $43.4^{\circ} \mathrm{C}$ indicate a transition at this temperature.

was approached from undersaturated and supersaturated solutions, and care was taken to assure ourselves which crystalline form was present. This has necessitated discarding some of the earlier determinations, especially those at $50^{\circ} \mathrm{C}$, when erratic values were undoubtedly caused by the presence of both crystalline forms. 
Solubility curves of the two crystalline forms intersect at $43.4^{\circ} \mathrm{C}$, which is therefore the transition temperature. This is confirmed by the measurements of emf. Measurements of the solubility of $\mathrm{CdSO}_{4} .8 / 3 \mathrm{H}_{2} \mathrm{O}$ have been extended above $43^{\circ}$, although the salt is metastable above this temperature. This can be done only under the condition that no other modification of the salt is present. Up to $50^{\circ} \mathrm{C}$ the results fall on an extension of the curve for the solubility of $\mathrm{CdSO}_{4} .8 / 3 \mathrm{H}_{2} \mathrm{O}$ below the transition temperature. Either metastable modification is more soluble than the stable modification at the same temperature.

Vosburgh and Eppley [9] determined the relation between emf and concentration of cadmium sulfate in unsaturated standard cells. By using their data, our observed differences in emf for the two kinds of cells, and the measured solubility of $\mathrm{CdSO}_{4} \cdot 8 / 3 \mathrm{H}_{2} \mathrm{O}$, it is possible to estimate the solubility of the metastable salt at temperatures below the transition point. For example, the calculated value at $25^{\circ} \mathrm{C}$ is 0.0726 mole of $\mathrm{CdSO}_{4}$ per mole of water. This value lies on a linear extension of the monohydrate curve of figure 1 . It appears to be entirely possible to make measurements of the solubility of this salt in the region of its metastability, but this has not been done.

\section{ELECTROMOTIVE FORCE}

Wide differences between the emf of the two kinds of cells are apparent, except at the transition point, $43.4^{\circ} \mathrm{C}$, where the emf are equal. The observed values are given in table 2 and figure 1. Curve 1 in figure 1 is for cells containing the usual salt, $\mathrm{CdSO} \mathrm{SO}_{4} \cdot 8 / 3 \mathrm{H}_{2} \mathrm{O}$. These cells are the ordinary saturated type. Above $43^{\circ} \mathrm{C}$ the cells are in a metastable condition. The general characteristic of these cells shows a decreasing emf with increasing temperature, that is, the temperature coefficient is negative. Particular values of emf read from the curve agree substantially with values computed from the international temperature formula [10]. These cells are, therefore, representative of Weston normal cells, and they provide a satisfactory criterion by which to judge the monohydrate cells.

TABLE 2.-Observed electromotive forces

[Values are given in the order in which they were taken]

\begin{tabular}{|c|c|c|c|c|c|c|}
\hline \multirow{2}{*}{$\begin{array}{l}\text { Temper- } \\
\text { ature }\end{array}$} & \multicolumn{3}{|c|}{ Cells with $\mathrm{CdSO}_{4} \cdot 8 / 3 \mathrm{H}_{2} \mathrm{O}(\mathrm{s})$} & \multicolumn{3}{|c|}{ Cells with $\mathrm{CdSO}_{4} \cdot \mathrm{H}_{2} \mathrm{O}(\mathrm{s})$} \\
\hline & No. 1028 & No. 1030 & Mean & No. 1026 & No. 1027 & Mean \\
\hline${ }^{\circ} \mathrm{C}$ & Int. volts & Int. volts & Int. volts & Int. volts & Int. volts & Int. volts \\
\hline 42.90 & 1.016986 & 1. 017005 & 1. 016996 & 1. 016879 & 1.016871 & 1. 016875 \\
\hline 47.87 & 6619 & 6625 & 6622 & 7659 & 7693 & 7676 \\
\hline 25.58 & 8082 & 8089 & 8086 & 3937 & 3932 & 3934 \\
\hline 18. 66 & 8369 & 8369 & 8369 & 2799 & 2824 & 2812 \\
\hline $\begin{array}{l}20.07 \\
23.56\end{array}$ & 8323 & 8324 & 8324 & & & \\
\hline 23.56 & 8173 & 8182 & 8178 & 3578 & 3569 & 3574 \\
\hline 29.66 & 7850 & 7855 & 7852 & 4638 & 4637 & 4638 \\
\hline 36.81 & 7408 & 7409 & 7409 & 5833 & 5849 & 5841 \\
\hline $\begin{array}{l}43.51 \\
48.90\end{array}$ & 6940 & 6941 & 6941 & 6986 & 6956 & 6971 \\
\hline $\begin{array}{l}48.90 \\
49.94\end{array}$ & $\begin{array}{l}6550 \\
6475\end{array}$ & $\begin{array}{l}6559 \\
6458\end{array}$ & $\begin{array}{l}6555 \\
6467\end{array}$ & 8077 & & 8077 \\
\hline 43.90 & 6932 & 6921 & 6926 & 7078 & $7090^{\circ}$ & 7084 \\
\hline
\end{tabular}


Electromotive forces of the cells containing $\mathrm{CdSO}_{4} \cdot \mathrm{H}_{2} \mathrm{O}$, which is metastable at all temperatures below $43^{\circ}$, curve 2 of figure 1 , are noticeably lower in this range. For these the temperature coefficient is positive. The measurements on these cells could not be extended above $50^{\circ} \mathrm{C}$, because of limitations imposed by the cadmium amalgam employed in constructing them. This contained 10 percent of cadmium by weight. Such an amalgam at ordinary temperatures consists of both solid and liquid phases; but when the temperature is raised above $50^{\circ} \mathrm{C}$, the solid phase is completely converted into the liquid phase, and the emf of the cells begins to fall rapidly.

Electromotive forces at uniform temperature intervals read from the curves are given in table 3.

TABLE 3.-Electromotive forces of cells containing $\mathrm{CdSO}_{4} \cdot 8 / 3 \mathrm{H}_{2} \mathrm{O}$ and $\mathrm{CdSO}_{4} \mathrm{H}_{2} \mathrm{O}$

\begin{tabular}{|c|c|c|}
\hline \multirow{2}{*}{$\begin{array}{c}\text { Temper- } \\
\text { ature }\end{array}$} & \multicolumn{2}{|c|}{ Electromotive force } \\
\cline { 2 - 3 } & $\mathrm{CdSO}_{4} \cdot 8 / 3 \mathrm{H}_{2} \mathrm{O}(\mathrm{s})$ & $\mathrm{CdSO}_{4} \cdot \mathrm{H}_{2} \mathrm{O}(\mathrm{s})$ \\
\hline${ }^{\circ} \mathrm{C}$ & Int. volts & Int. volts \\
20 & 1.01832 & 1.01300 \\
25 & 810 & 384 \\
30 & 783 & 468 \\
35 & 751 & 553 \\
40 & 718 & 638 \\
43.4 & 695 & 695 \\
45 & 682 & 723 \\
50 & 649 & 808 \\
\hline
\end{tabular}

\section{TEMPERATURE COEFFICIENT}

The change in emf per degree change in temperature can be obtained from the curves plotted in figure 1 . For the cells made with the usual salt, $\mathrm{CdSO}_{4} \cdot 8 / 3 \mathrm{H}_{2} \mathrm{O}$, values of the coefficient change with temperature. The international formula for the relation of emf to temperature is

$$
\begin{gathered}
\boldsymbol{E}_{t}=\boldsymbol{E}_{20}-0.0000406\left(t-20^{\circ}\right)-0.00000095\left(t-20^{\circ}\right)^{2}+ \\
0.00000001\left(t-20^{\circ}\right)^{3} .
\end{gathered}
$$

Wolff's work [11], on which this formula was based extended from $0^{\circ}$ to $40^{\circ} \mathrm{C}$. It applies reasonably well, however, to $50^{\circ} \mathrm{C}$. Beyond this point our values for the emf are not sufficiently reliable for a comparison to be made, the reason being uncertainty as to the condition of the amalgam.

The monohydrate cells have a linear relationship between temperature and emf in the range of the measurements. Between $20^{\circ}$ and $50^{\circ} \mathrm{C}$ the formula can be expressed as

$$
\boldsymbol{E}_{\boldsymbol{t}}=\boldsymbol{E}_{43.4}+0.000173\left(t-43.4^{\circ}\right),
$$

Where $\boldsymbol{E}_{43.4}$ is the emf at $43.4^{\circ} \mathrm{C}$, the equilibrium temperature for the two hydrates, and has the value 1.01695 international volts. 


\section{THERMODYNAMIC DISCUSSION OF THE REACTION}

The chemical reactions which take place in the two cells may be represented by the equations:

$\begin{aligned} \mathrm{Cd}(\text { amalgam }) & +\left(\frac{8 / 3}{m_{1}-8 / 3}\right)\left[\mathrm{CdSO}_{4} \cdot m_{1} \mathrm{H}_{2} \mathrm{O}\right](\text { saturated soln })+ \\ \mathrm{Hg}_{2} \mathrm{SO}_{4}(\mathrm{~s}) & \rightleftarrows\left(\frac{m_{1}}{m_{1}-8 / 3}\right)\left[\mathrm{CdSO}_{4} \cdot 8 / 3 \mathrm{H}_{2} \mathrm{O}\right](\mathrm{s})+2 \mathrm{Hg}(\mathrm{l})\end{aligned}$

$\mathrm{Cd}($ amalgam $)+\left(\frac{1}{m_{2}-1}\right)\left[\mathrm{CdSO}_{4} \cdot m_{2} \mathrm{H}_{2} \mathrm{O}\right]($ saturated soln $)+\mathrm{Hg}_{2} \mathrm{SO}_{4}(\mathrm{~s})$

$$
\rightleftarrows\left(\frac{m_{2}}{m_{2}-1}\right)\left[\mathrm{CdSO}_{4} \cdot \mathrm{H}_{2} \mathrm{O}\right](\mathrm{s})+2 \mathrm{Hg}(\mathrm{l}),
$$

where $m_{1}$ and $m_{2}$ are the number of moles of $\mathrm{H}_{2} \mathrm{O}$ associated with 1 mole of $\mathrm{CdSO}_{4}$ in saturated solutions of the respective salts.

Since the free energy per mole of $\mathrm{CdSO}_{4}$ is the same in the saturated solution as in the crystal in equilibrium with that solution, and since the free energy per mole of $\mathrm{H}_{2} \mathrm{O}$ is the same in the solution as in the crystal, for considerations of free energy changes in the cells these complete equations may be simplified.

Reaction 1 may be written as

$\mathrm{Cd}$ (amalgam) $+\mathrm{Hg}_{2} \mathrm{SO}_{4}(\mathrm{~s}) \rightleftarrows 2 \mathrm{Hg}(\mathrm{l})+\mathrm{CdSO}_{4}$

and reaction 2 as

$\mathrm{Cd}($ amalgam $)+\mathrm{Hg}_{2} \mathrm{SO}_{4}(\mathrm{~s}) \rightleftarrows 2 \mathrm{Hg}(\mathrm{l})+\mathrm{CdSO}_{4}$ (in saturated $\mathrm{CdSO}_{4} \cdot \mathrm{H}_{2} \mathrm{O}$ soln).

Equation 1a minus eq 2a gives

$\mathrm{CdSO}_{4}$ (in saturated $\mathrm{CdSO}_{4} \cdot \mathrm{H}_{2} \mathrm{O}$ soln $) \rightleftarrows \mathrm{CdSO}_{4}$

$$
\text { (in saturated } \mathrm{CdSO}_{4} .8 / 3 \mathrm{H}_{2} \mathrm{O} \text { soln). }
$$

The free energy changes accompanying these reactions are

$$
\begin{aligned}
& \text { for eq } 1, \Delta F_{1}=-2 F E_{1} \\
& \text { for eq } 2, \Delta F_{2}=-2 F E_{2} \text {, and } \\
& \text { for eq } 3, \Delta F_{3}=\Delta F_{1}-\Delta F_{2}=-2 F\left(E_{1}-E_{2}\right) \text {. }
\end{aligned}
$$

In these equations $\boldsymbol{F}$ is the value of the faraday and $\boldsymbol{E}_{1}$ and $\boldsymbol{E}_{2}$ are the emf of the $\mathrm{CdSO}_{4} \cdot 8 / 3 \mathrm{H}_{2} \mathrm{O}$ and $\mathrm{CdSO}_{4} \cdot \mathrm{H}_{2} \mathrm{O}$ cells, respectively. These are expressed as functions of the temperature in tables 2 and 3 and by the equations on page 461 .

$\Delta F_{3}$ is equal to the difference in the partial molal free energies of $\mathrm{CdSO}_{4}$ in aqueous solutions, whose concentrations determined by the two hydrates in equilibrium with the solutions, are given in table 1 and figure 1.

At $43.4^{\circ} \mathrm{C}$ the emf of the two cells were found to be equal, that is $\boldsymbol{E}_{1}=\boldsymbol{E}_{2}$, which makes $\Delta F_{3}=0$ and the compositions of the two saturated solutions the same at this temperature. It follows, therefore, from electrochemical data that at $43.4^{\circ} \mathrm{C}$ the two crystalline modifications, $\mathrm{CdSO}_{4} \cdot 8 / 3 \mathrm{H}_{2} \mathrm{O}$ and $\mathrm{CdSO}_{4} \cdot \mathrm{H}_{2} \mathrm{O}$, are in equilibrium with each other. The transition temperature determined in this way agrees to $0.2^{\circ} \mathrm{C}$ with that determined directly by solubility measurements. 
At temperatures below $43.4^{\circ} \mathrm{C}, \boldsymbol{E}_{1}$ is greater than $\boldsymbol{E}_{2}$, and $\Delta F_{3}$ therefore is negative. This means that at temperatures below $43.4^{\circ} \mathrm{C}$, reaction 3 proceeds in the direction in which it is written and $\mathrm{CdSO}_{4} \cdot 8 / 3 \mathrm{H}_{2} \mathrm{O}$ is more stable than $\mathrm{CdSO}_{4} \cdot \mathrm{H}_{2} \mathrm{O}$.

Since $\boldsymbol{E}_{1}$ is less than $\boldsymbol{E}_{2}$ above the transition temperature, $\Delta F_{3}$ in this range is positive and $\mathrm{CdSO}_{4} \cdot \mathrm{H}_{2} \mathrm{O}$ is more stable than $\mathrm{CdSO}_{4} \cdot 8 / 3 \mathrm{H}_{2} \mathrm{O}$.

\section{HYSTERESIS EFFECTS}

Hysteresis as a term applied to standard cells means abnormal temporary changes in emf resulting from abrupt changes in temperature. This defect, rarely serious in new cells of the ordinary type containing $\mathrm{CdSO}_{4} .8 / 3 \mathrm{H}_{2} \mathrm{O}$, may become a more serious source of error in old cells. On the other hand, the monohydrate cells exhibit large hysteresis effects even when new. When the temperature of the cells is increased, hysteresis effects are usually negligible in the ordinary type of cell, but a month or more may be required for the monohydrate cells to reach an equilibrium condition. When the temperature falls the monohydrate cells come to equilibrium more quickly, but several days may be required.

A comparison of the contrasting

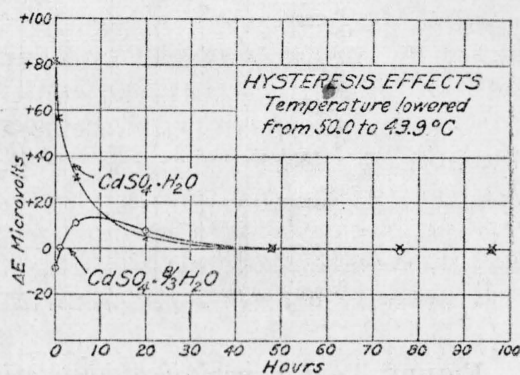

FiguRe 2.-Comparison of hysieresis effects when temperature was decreased.

$\Delta \boldsymbol{E}$ represents the difference in electromotive force from the equilibrium value at the final temperature.

conditions of the two types of cells when subjected to changes of temperature is given in the following summary. It is evident that the larger hysteresis effect in both types of cells is associated with the temperature change which produces a precipitation of salt.

\begin{tabular}{l|l|l}
\hline Temperature & Cells containing $\mathrm{CdSO}_{4} \cdot 8 / 3 \mathrm{H}_{2} \mathrm{O}$ & Cells containing $\mathrm{CdSO}_{4} \cdot \mathrm{H}_{2} \mathrm{O}$ \\
\hline Increased_..- & $\begin{array}{l}\text { Salt dissolved. } \\
\text { Emf decreased. } \\
\text { Little or no hysteresis. }\end{array}$ & $\begin{array}{l}\text { Salt precipitated. } \\
\text { Emf increased. } \\
\text { Large hysteresis effect. }\end{array}$ \\
Decreased_.-- & $\begin{array}{l}\text { Salt precipitated. } \\
\text { Emf increased. } \\
\text { More hysteresis than above. }\end{array}$ & $\begin{array}{l}\text { Salt dissolved. } \\
\text { Emf decreased. } \\
\text { Much less hysteresis effect than } \\
\text { above. }\end{array}$ \\
\hline
\end{tabular}

The two types of cells contain identical materials except for the crystalline state of the cadmium salt, and it would seem that hysteresis, which has been attributed to many causes, is in part at least associated with the crystallization of the salt. New possibilities of studying the cause of hysteresis remain to be investigated.

Quantitative data on differences of emf, $\Delta \mathbb{E}$, from equilibrium values as a function of time are given in figures 2 and 3 . The first of these compares values of $\Delta \boldsymbol{E}$ for each type of cell when the tempera- 
ture was decreased from $50^{\circ}$ to about $44^{\circ} \mathrm{C}$. Figure 3 shows values of $\Delta \boldsymbol{E}$ of the same cells when the temperature was raised from about $37^{\circ}$ to $43.5^{\circ} \mathrm{C}$. In figure 3 it may be seen that much more time was required for cells containing $\mathrm{CdSO}_{4} \cdot \mathrm{H}_{2} \mathrm{O}$ to reach equilibrium than when the temperature was lowered, figure 2 , by approximately the same number of degrees. Obviously, if the cells containing $\mathrm{CdSO}_{4} \cdot \mathrm{H}_{2} \mathrm{O}$ are to be of any practical value, hysteresis and the large temperature coefficient will necessitate good thermostatic control.

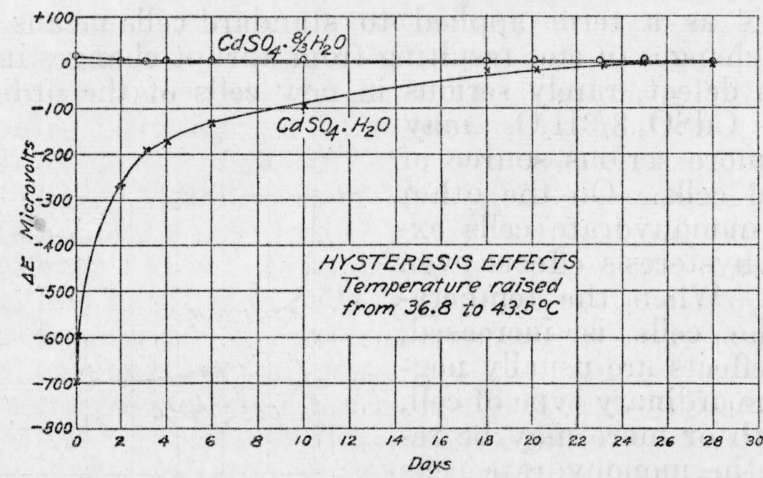

FIGURE 3.-Comparison of hysteresis effects when temperature was increased.

$\Delta \boldsymbol{E}$ represents the difference in electromotive force from the equilibrium value at the final temperature.

\section{CONCLUSIONS}

New lines of investigation on standards of emf are suggested by the results reported in this paper, but more work is needed before attempting to generalize too broadly. However, some of the more obvious practical considerations may be mentioned.

1. The stability of cells containing the metastable form of $\mathrm{CdSO}_{4}$ at ordinary temperatures is sufficient to warrant a more careful study of these cells. They have been carried through a temperature cycle extending $25^{\circ}$ below the transition point without indication of appreciable change, and they could of course be maintained indefinitely at a temperature of $43.4^{\circ} \mathrm{C}$ or more. Another form of saturated standard cell which has radically different properties from the customary Weston normal cell is therefore possible.

2. The transition temperature from $\mathrm{CdSO}_{2} .8 / 3 \mathrm{H}_{3} \mathrm{O}$ to $\mathrm{CdSO}_{4} \cdot \mathrm{H}_{2} \mathrm{O}$, which is $43.4^{\circ} \mathrm{C}$, fixes an upper limit of temperature for the preparation of recrystallized salt to be used in the ordinary type of cell.

3 . Since the temperature coefficient of the ordinary type of cell is negative and of the monohydrate type positive, it is possible to make combinations which would have very small values of $\Delta \boldsymbol{E} / \Delta \boldsymbol{T}$ over a limited range of temperatures. The value in volts of $\Delta \boldsymbol{E} / \Delta \boldsymbol{T}$ at the transition temperature is -0.000069 for the ordinary cells and +0.000173 for cells containing $\mathrm{CdSO}_{4} \cdot \mathrm{H}_{2} \mathrm{O}$. A series-connected combination of five of the former and two of the latter would have an emf which would change less than 1 part in 1 million per degree centigrade.

4. The contrasting hysteresis effects of the two types of cells suggest new methods of studying the causes of hysteresis. Obviously, close 
regulation of temperature is necessary if satisfactory results are to be obtained with cells containing $\mathrm{CdSO}_{4} \cdot \mathrm{H}_{2} \mathrm{O}$.

5 . The transition temperature, $43.4^{\circ} \mathrm{C}$, between the two forms of cadmium sulfate is a fixed constant of nature which may ultimately be determined with greater accuracy than has been possible in the present work. At this transition temperature the emf of two differing types of cells containing the respective salts must be equal, assuming that the individual cells are not subject to secondary effects caused by impurities, variations in acidity, etc. The cells represented by eq 1 and 2 on page 462 are, for the present discussion, considered as ideal cells, differing only in the crystal structure of the cadmium sulfate. They are both in stable equilibrium at the transition temperature and should, therefore, be permanent. The numerical value assigned to the emf at this point depends on the units employed. In the present paper the results are given in terms of international volts, but whatever units may be chosen, equality of emf of the two systems at the transition temperature is independent of the units. One type of cell serves as a check on the other, and when equality of emf is obtained at the known transition temperature, the measurement carries the proof of its own validity. It might serve also as a means for judging the constancy of groups of cells over a period of time, since any variation of the temperature at which their respective emf are equal would mean that one or both of them were varying for reasons not expressed in eq 1 and 2 on page 462 . On the other hand, if the two kinds of cells continued for a long period of time to have the same emf at the fixed transition temperature, it would be good evidence of the constancy of both, and the laboratory would have a new and radically different means of judging the constancy of its reference standard. Such a goal, however, could be attained only as a result of more precise work on the monohydrate cell than has been possible at this time.

\section{REFERENCES}

[1] F. Mylius and F. Funk, Ber. deut. chem. Ges. 30, 824 (1897).

W. Jaeger, Die Normalelemente, p. 83 (1902).

F. A. Wolff and C. E. Waters, Bul. BS 3, 629 (1907) S67.

F. E. Smith, Phil. Trans. 207, 396 (1908).

G. A. Hulett, Phys. Rev. 32, 268 (1911).

[2] H. O. Hofman and W. Wanjukow, Trans. Am. Inst. Mining Engrs. 43, $563(1912)$.

[3] C. D. Carpenter and E. R. Jette, J. Am. Chem. Soc. 45, 578 (1923).

[4] E. Wiedemann, Wied. Ann. 17, 572 (1882).

Lord Rayleigh, Trans. Roy. Soc. (London) 176, 781 (1885).

E. Cohen, Z. phys. Chem. 14, 53 (1894).

H. L. Callendar and H. T. Barnes, Proc. Roy. Soc. (London) 62, 150 (1897).

W. Jaeger, Wied. Ann. 63, 354 (1897).

H. T. Barnes, J. Phys. Chem. 4, 1 (1900).

[5] F. A. Wolff and C. E. Waters, Bul. BS 4, 1 (1907) S70.

[6] Unpublished records of the NBS.

[7] H. B. Brooks, BS J. Research 11, 211 (1933) RP 586.

[8] Int. Crit. Tables 4, 222 (1928).

[9] W. Vosburgh and M. Eppley, J. Am. Chem. Soc. 45, 2271 (1923).

[10] Report of London Conference on Electrical Units and Standards (1908).

[11] F. A. Wolff, Bul. BS 5, 309 (1908) S104.

Washington, January 6, 1941. 


\section{MATHEMATICAL TABLES}

Attention is invited to a series of publications which is being prepared by the Project for the Computation of Mathematical Tables conducted by the Federal Works Agency, Work Projects Administration for the City of New York under the sponsorship of the National Bureau of Standards.

To date five tables have been made available through the National Bureau of Standards. These are listed below:

MT1. Table of the First Ten Powers of the Intrgers From 1 to 1000:

(1938) VIII + 80 pages; heavy paper cover. 50 cents.

MT2. Tables of the Exponential Function $e^{x}$ :

The ranges and intervals of the argument and the number of decimal places in the entries are given below:

$\begin{array}{ccc}\text { Range of } x & \begin{array}{c}\text { Interval } \\ \text { of } x\end{array} & \begin{array}{c}\text { Number of decimals } \\ \text { given }\end{array} \\ -2.5000 \text { to } 1.0000 & 0.0001 & 18 \\ 1.0000 \text { to } 2.5000 & .0001 & 15 \\ 2.500 \text { to } 5.000 & .001 & 15 \\ 5.00 \text { to } 10.00 & .01 & 12\end{array}$

(1939) XV + 535 pages; bound in buckram, $\$ 2.00$.

MT3. Tables of Circular and Hyperbolic Sings and Cosines for Radian Arguments:

Contains 9 decimal place values of $\sin x, \cos x, \sinh x$ and $\cosh x$ for $x$ (in radians) ranging from 0 to 2 at intervals of 0.0001 .

(1939) XVII + 405 pages; bound in buckram, $\$ 2.00$.

MT4. Tables of Sines and Cosines for Radian Arguments:

Contains 8 decimal place values of sines and cosines for radian arguments ranging from 0 to 25 at intervals of 0.001 .

(1940) XXIX + 275 pages; bound in buckram, $\$ 2.00$.

MT5. Tables of Sine, Cosine, and Exponential Integrals, Volume I:

Values of these functions to 9 places of decimals from 0 to 2 at intervals of 0.0001 .

(1940) XXVI+444 pages; bound in buckram, $\$ 2.00$.

Payment is required in advance. Make remittance payable to the "National Bureau of Standards", and send with order, using the blank form on the page facing this one for the purpose.

Above prices are for delivery in the United States and its possessions and in countries extending the franking privilege. To other countries the price of MT1 is 65 cents and that of MT2, MT3, MT4, and MT5 is $\$ 2.50$ each; remittance to be made payable in United States currency.

Copies of these publications have been sent to various Government depositories throughout the country, such as public libraries in large cities, and colleges and universities, where they can be consulted.

A mailing list is maintained for those who desire to receive announcements regarding new tables as they become available. A list of the tables it is planned to publish will be sent on request. 